\title{
Morphological Diversity of Phomopsis vaccinii Isolates from Cranberry (Vaccinium macrocarpon Ait.) in Latvia
}

\author{
Liga Vilka ${ }^{*}$, Julija Volkova ${ }^{2}$ \\ ${ }^{1}$ Latvia University of Agriculture, Liela str.2, Jelgava, LV-3001, Latvia \\ ${ }^{2}$ Latvian Plant Protection Research centre, Struktoru str. 14a, Riga, Lv-1039, Latvia
}

\begin{abstract}
Phomopsis vaccinii cause a serious disease of blueberry, cranberry and other Vaccinium crops in the North America and Europe as well. Over 1000 species names are described by Phomopsis spp., but their biology and life style are mostly unknown. Identification of $P$. vaccinii by methods of classical phytopathology is difficult and complicate, because many species are morphologically similar to $P$. vaccinii, and $P$. vaccinii itself has diverse patterns of colony morphology. For this investigation $P$. vaccinii isolates were obtained from five cranberry plantations in different locations of Latvia (Babite, Alsunga, Rucava, Ape and Pargauja municipality) from berries affected by viscid rot at harvest and storage in 2010. Altogether 44 P. vaccinii isolates were cultivated on potato dextrose agar for description of colony morphology. In order to find some relationships between samples, the isolates were arranged in different groups on the basis of mycelium color and structure (zoning), reverse pigmentation, pycnidium formation time, size, location, number and size of conidia. During this study the colonies of $P$. vaccinii from cranberry in Latvia showed different morphological features in culture and no relationships between growing regions and groups of isolates were found. P. vaccinii is easy to confuse with other Phomopsis species if only classical phytopathological methods are used.
\end{abstract}

Key words: Phomopsis vaccinii, colony morphology, mycelium, pycnidia, conidia.

\section{Introduction}

The plantations of American cranberry in Latvia enlarge every year because of high production demand in the market of Latvia and Europe, but fruit rot reduces quality of berries in storage (Vilka and Bankina, 2013). Nine pathogens are detected from cranberry in Latvia. Fusicoccum putrefaciens and Coleophoma empetri are the most common in cranberry plantations and storage in Latvia (Vilka et al., 2009, Vilka and Bankina, 2013). One of the harmful pathogens in the future could be Phomopsis vaccinii. Although overall incidence of $P$. vaccinii is still low in Latvia, it is isolated from upright dieback, flowers and ovaries in cranberry plantations and mostly causes viscid rot in storage (Vilka et al., 2009).

Vaccinium macrocarpon (American cranberry) and $V$. corymbosum (highbush blueberry) were introduced from North America and now are widely commercially cultivated in Europe (Lombard et al., 2014). In Latvia, cranberry and blueberry growing has become more popular since 1990, and both are rated as some of the most succesful comercial fruit crops at the moment.

P. vaccinii cause a serious disease of blueberry, cranberry and other Vaccinium crops in the North America. P. vaccinii was considered to be of minor importance in the late 1940s (Bergman and Wilcox, 1936), but disease became serious in some areas of Wisconsin in 1966. From 1975 it was reported that pathogen could be epidemic in some southern regions and $P$. vaccinii was considered to be a serious pathogen under favorable conditions (Weingartner and Klos, 1975).

The genus Vaccinium contains approximately 450 species of woody, perennial shrubs belonging to the family Ericaceae (heath). Four Vaccinium spp. are regarded as economically important and indigenous to Europe, namely V. myrtillus (bilberry), V. oxycoccus (cranberry), V. uliginosum (bog bilberry) and $V$. vitis-idaea (lingonberry). Several Diaporthe and Phomopsis spp. have been reported from Vaccinium spp., including $P$. vaccinii, which is globally regarded as an important species of Phomopsis/Diaporthe (Lombard et al., 2014).

P. vaccinii is under a strict control in Europe as well as in Latvia and included into the A2 (2010 transferred from A1 (1995) list of Quarantine Pests of European and Mediterranean Plant Protection Organization (EPPO) and into the list of Quarantine Pests of Latvia. P. vaccinii is also listed in Annex II AI of Directive 2000/29/EC (European Food Safety Authority, 2014).

In Europe, P. vaccinii has been eradicated in Germany, Romania, the United Kingdom and the Netherlands (European Food Safety Authority, 2014, Diaporthe vaccinii, 2009), but in Lithuania it

\footnotetext{
* Corresponding Author's email: liga.vilka@gmail.com
} 
was isolated also from wild species (Kačergius and Jovaišiené, 2010).

The teleomorph stage of this fungus was described as Diaporthe vaccinii Shear, but in recent years researchers doubt its existence; therefore, they use more Phomopsis and sometimes Diaporthe like a synonym (Udayanga et al., 2011, Gomes et al., 2013, Udayanga et al., 2014a, 2014b).

In the recent years over 1000 species names are described in the genus Phomopsis, but their biology and life style are still unknown or not studied enough. The identification of $P$. vaccinii is difficult and complicated if only classical phytopathological methods are used, because many species have similar morphological characteristics, but $P$. vaccinii also shows diversity of colony morphology (Udayanga et al., 2011, Farr et.al., 2002).

The aim of the study was to compare $P$. vacccinii isolates from different cranberry locations in Latvia and to describe their morphology in culture.

\section{Materials and Methods}

The $P$. vaccinii isolates were obtained from five cranberry plantations in different locations of Latvia (Babite, Alsunga, Rucava, Ape and Pargauja municipality) from berries with typical symptoms of viscid rot at harvest and storage in 2010. The samples were taken from the cranberry cultivar 'Stevens'.

The number of isolates from plantations depended on incidence of viscid rot and differences of colony. Most samples were taken from Babite municipality (22 isolates; 50\%), Rucava - 12 (27\%), Alsunga - 7 (16\%), Ape - $2(5 \%)$ and Pargauja - $1(2 \%)$.

For examination of colony morphology 44 isolates of $P$. vaccinii were cultivated on potato dextrose agar (PDA) in two replicates. Cultures were incubated at $23{ }^{\circ} \mathrm{C}$ in the dark for one month.

Growth rate of colonies was recorded after 4, 6, 7, 8 and 9 days; color and structure of surface mycelium; reverse pigmentation (color); zonate development of mycelia and pycnidia as described bellow (Ulloa and Hanlin, 2002).

During this study the isolates were arranged in different groups with similar descriptions to find some relationships between samples (Table 1).

Conidia from 26 isolates were described. The length and width of 100 conidia per each isolate were measured $(\mu \mathrm{m})$.

In addition, the taxonomical identity of isolates from representative groups $(n=15)$ was confirmed

Morphological criteria used to group the isolates

Table 1

\begin{tabular}{|c|c|c|}
\hline Assessment timing & Morphological characteristics & Variations \\
\hline $\begin{array}{l}\text { After } 4,6 \text { days and } 1 \\
\text { month }\end{array}$ & Color of surface mycelium & $\begin{array}{l}\text { grayish white (light) } \\
\text { grayish brown (dark) }\end{array}$ \\
\hline After 1 month & Reverse pigmentation & $\begin{array}{l}\text { dark brown centre, at the edge grayish white } \\
\text { creamy white } \\
\text { dark gray } \\
\text { dark brown }\end{array}$ \\
\hline $\begin{array}{l}\text { After } 4,6 \text { days and } 1 \\
\text { month }\end{array}$ & Structure of surface mycelia & $\begin{array}{l}\text { zonate colony (concentric circles) } \\
\text { non zonate colony }\end{array}$ \\
\hline First time when observed & Appearance of pycnidia & $\begin{array}{l}\text { in } 7 \text { days (after inoculation) } \\
\text { in } 8 \text { days } \\
\text { more than } 8 \text { days, about } 1 \text { month from } \\
\text { inoculation }\end{array}$ \\
\hline Once, after 1 month & Location of pycnidia & $\begin{array}{l}\text { in the centre on circles } \\
\text { scattered }\end{array}$ \\
\hline Once, after 1 month & Number of pycnidia & $\begin{array}{l}0-10 \\
11-20 \\
>21\end{array}$ \\
\hline Once, after 1 month & Size of pycnidia & $\begin{array}{l}0-0.9 \mathrm{~mm} \\
1-3 \mathrm{~mm}\end{array}$ \\
\hline
\end{tabular}




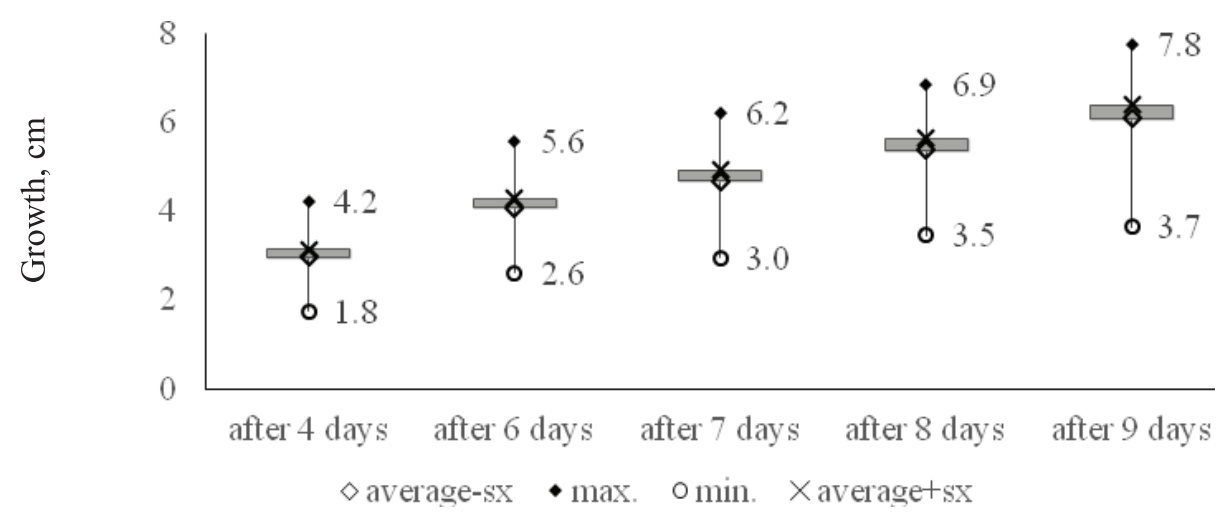

Figure 1. The dynamic of colonies growth (in diameter, $\mathrm{cm}$ ) on

PDA for different isolates of $P$. vaccinii.

by ITS1-5.8S-ITS2 region sequencing. Extraction of rDNA and PCR conditions performed as previously described (Farr et al., 2002, Kačergius and Jovaisiene, 2010). Purified PCR products were sequenced at Macrogen Europe (Amsterdam, Netherlands). Obtained sequences were compared to sequences of $P$. vaccinii and closely related taxa available in data base of NCBI GeneBank BLASTn. For more accurate identification additional phylogenetic test using sequences of CBS reference isolates were performed using Maximal parsimony method and bootstraping within the MEGA 5.1. software (Tamura et al., 2011). Preparing of samples for sequencing and data analysis was performed in the laboratory of Latvian Plant Protection Research centre. Sequences were deposited at NCBI GeneBank and are accessible by ID KP869876 - KP869890.
The results were statistically processed with Microsoft Excel for windows and the computer program SPSS 17.0 statistics package. The obtained data were analysed using Pearson correlation coefficient for every pair of traits in the SPSS 17.0 statistical package procedure $(p<0.05$; $\mathrm{p}<0.001)$.

\section{Results}

Colony growth. After four days of cultivation different growth rate of $P$. vaccinii was observed. $16 \%$ of isolates, mainly from Rucava and Babite reached $1.8-2.5 \mathrm{~cm}$ in diameter. Slightly faster growth of colonies was observed in the main part of isolates $(70 \%)$, the diameter reached $2.6-3.5 \mathrm{~cm}$. Only for $14 \%$ of isolates the measured diameter was $3.7-4.4 \mathrm{~cm}$.

Table 2

\section{Characterizations of surface mycelium of $P$. vaccinii isolates from different cranberry growing regions}

\begin{tabular}{|c|c|c|c|c|c|c|}
\hline Region & $\begin{array}{l}\text { Mycelium color } \\
\text { after one month }\end{array}$ & $\begin{array}{l}\text { Number } \\
\text { of isolates }\end{array}$ & Percent & $\begin{array}{l}\text { Zonate } \\
\text { (circle) }\end{array}$ & $\begin{array}{l}\text { Number of } \\
\text { isolates }\end{array}$ & Percent \\
\hline \multirow[t]{3}{*}{ Rucava } & grayish white & 9 & 75 & yes & 9 & 75 \\
\hline & grayish brown & 3 & 25 & no & 3 & 25 \\
\hline & Total & 12 & 100 & Total & 12 & 100 \\
\hline Alsunga & grayish white & 7 & 100 & yes & 7 & 100 \\
\hline \multirow[t]{3}{*}{ Babite } & grayish white & 18 & 82 & yes & 21 & 95 \\
\hline & grayish brown & 4 & 18 & no & 1 & 5 \\
\hline & Total & 22 & 100 & Total & 22 & 100 \\
\hline Pargauja & grayish white & 1 & 100 & no & 1 & 100 \\
\hline Ape & grayish white & 2 & 100 & yes & 2 & 100 \\
\hline
\end{tabular}




\section{Colony pigmentation of $\boldsymbol{P}$. vaccinii in culture (reverse) divided} in groups by geographical location

Table 3

\begin{tabular}{lccccc}
\hline \multirow{2}{*}{$\begin{array}{l}\text { Growing } \\
\text { region }\end{array}$} & $\begin{array}{c}\text { dark brown centre, } \\
\text { grayish white } \\
\text { periphery }\end{array}$ & creamy white & dark brown & dark grey & $\begin{array}{c}\text { Number of } \\
\text { analyzed isolates }\end{array}$ \\
\hline Rucava & 8.3 & 41.7 & 50 & 0 & 12 \\
\hline Alsunga & 71.4 & 14.3 & 14.3 & 0 & 7 \\
\hline Babite & 45.5 & 31.8 & 4.5 & 18.2 & 22 \\
\hline Pargauja & 0 & 100 & 0 & 0 & 1 \\
\hline Ape & 50 & 50 & 0 & 0 & 2 \\
\hline & & & & Total & 44 \\
\hline
\end{tabular}

After six days the colony growth changed for some isolates and differences leveled off: 18\% of isolates were slow growing (2.6 $-3.5 \mathrm{~cm}$ in diam.), $47 \%$ of isolates were medium in size $(3.8-4.4 \mathrm{~cm}$ in diam.) and $34 \%$ of isolates showed faster growth (4.5 - $5.6 \mathrm{~cm}$ in diam.).

In the next days the colony diameter slightly increased, and at $8^{\text {th }}$ day the growth of some isolates stopped at all. For $20 \%$ of isolates the colony diameter reached $3.5-4.5 \mathrm{~cm}$; for another $20 \%-4.9$ $-5.5 \mathrm{~cm}$ and for $60 \%-5.6-6.9 \mathrm{~cm}$. In the last day the growth of most isolates stopped. In this study the growth of $P$. vaccinii significantly increased at first assessment, four days after inoculation (Figure 1). Although different growth of colonies was observed, no relationships between it and cranberry growing regions were found ( $r=0.183 ; p=0.233$ ).

Mycelium color. At the first assessment (4 days after inoculation) all colonies produced white mycelia; it was not compact, flat, cottony and produced lobate and entire margin. After one month the surface mycelium of $84 \%$ of isolates became grayish white, only some isolates from Rucava and Babite produced grayish brown mycelia (Table 2), but no relevance between growing site and color of mycelia ( $r=-0.110 ; p=0.477)$.

One of the peculiarities of $P$. vaccinii is production of zonate colonies as a result of mycelium development in concentric circles. For some isolates first signs of thickened mycelia were observed at first assessment. The main part of isolates (89\%) produced zonate colonies, including all isolates with light mycelia, except one from Pargauja (Table 2). The isolates with grayish white and grayish brown mycelium could also form zonate colonies, thereby no relevance was found between mycelium color and zoning $(r=0.040 ; p=0.796)$.

After 9 days the colonies showed different pigmentation in reverse. The pigmentation varied by isolates. $41 \%$ of isolates from Rucava showed creamy white pigmentation. Mainly isolates with dark brown centre and grayish white periphery were observed from Alsunga (71.4\%) and Babite (45.5\%) (Table 3, Fig.3), but no relevance was found between growing site and reverse pigmentation $(r=-0.192 ; p=0.211)$. In all inspected plantations, isolates with creamy white pigmentation were present. Positive correlation was detected between color of mycelia and pigmentation $(r=0.719 ; p<0.001)$ - colonies with grayish white mycelia produced creamy white pigmentation.

The colonies produced slightly embedded, dark, spherical pycnidia, which started to form in $7-8$ days (55\% isolates) after plugs with mycelia were transferred on PDA. $45 \%$ of isolates showed pycnidia later than 8 days until the end of one month from inoculation (Figure 2). The correlation was weak negative between time and number of pycnidia ( $r=-0.308, p=0.042$ ), so increasing days number of pycnidia will not increase (Table 3 ).

The number, size and placement of pycnidia on PDA were recorded after one month, and differences between isolates were found: $39 \%$ of isolates showed less than 10 pycnidia per plate, but the main part of isolates $(62 \%)$ produced more than 10 pycnidia per plate. $42 \%$ of isolates from Rucava, $57 \%$ from Alsunga and $32 \%$ from Babite showed less pycnidia. A part $(32 \%)$ of isolates formed more than 20 of pycnidia per plate; this ability was observed in $25 \%$ of isolates from Rucava, 14\% from Alsunga and 41\% from Babite, but no relevance was observed between 




Figure 2. Characterization of pycnidial development of $P$. vaccinii isolates on PDA.

growing site and number of pycnidia $(r=0.109$; $p=0.480$ ).

In this study, $61 \%$ of isolates produced pycnidia not only arranged in circles, but sometimes also scattered (Figure 3; Table 4). The main part of isolates produced circles, but they did not always form pycnidia ( $r=0.137 ; p=0.375$ ). $75 \%$ of isolates from Rucava and $68 \%$ form Babite, formed pycnidia scattered throughout the plate, but statistically no relevance was observed between growing site and place of formed pycnidia $(r=0.131 ; p=0.396)$.

Size of produced pycnidia was mainly $1-3 \mathrm{~mm}$ $(61 \%)$. The most isolates from Rucava $(78 \%)$, Babite
(57\%) and Alsunga (71\%) formed pycnidia with a size 1-3 mm arranged in circles (Table 4 ). $32 \%$ of all tested isolates formed pycnidia with a size less than $1 \mathrm{~mm}$ in circles, so no relevance was observed ( $r=-$ $0.246 ; p=0.107$ ).

Although statistically significant relationships between different morphological features of $P$. vaccinii isolates were not found (Table 4), some tendencies were observed (Table 5.). Colonies with creamy white pigmentation produced both types of circle (yes/no). Colonies, which produced circles, did not always form pycnidia and the number of pycnidia was not uniform at all plates.

Table 4

Relevance between morphological features of pycnidia produced in culture on PDA

\begin{tabular}{|c|c|c|c|c|c|}
\hline & & Time & Place & Number & Size \\
\hline \multirow{3}{*}{ Time } & Pearson Correlation & 1 &, 068 &,$- 308^{*}$ &, 162 \\
\hline & Sig. (2-tailed) & & ,660 &, 042 & ,294 \\
\hline & $\mathrm{N}$ & 44 & 44 & 44 & 44 \\
\hline \multirow{3}{*}{ Place } & Pearson Correlation &, 068 & 1 & ,270 &,- 246 \\
\hline & Sig. (2-tailed) & ,660 & & ,076 & ,107 \\
\hline & $\mathrm{N}$ & 44 & 44 & 44 & 44 \\
\hline \multirow{3}{*}{ Number } & Pearson Correlation &,$- \mathbf{3 0 8} *$ & 270 & 1 &,- 065 \\
\hline & Sig. (2-tailed) &, 042 &, 076 & & ,677 \\
\hline & $\mathrm{N}$ & 44 & 44 & 44 & 44 \\
\hline \multirow{3}{*}{ Size } & Pearson Correlation & , 162 &,- 246 &,- 065 & 1 \\
\hline & Sig. (2-tailed) & ,294 & ,107 &, 677 & \\
\hline & $\mathrm{N}$ & 44 & 44 & 44 & 44 \\
\hline
\end{tabular}

* Pearson Correlation is significant at 0.05 confidence level 


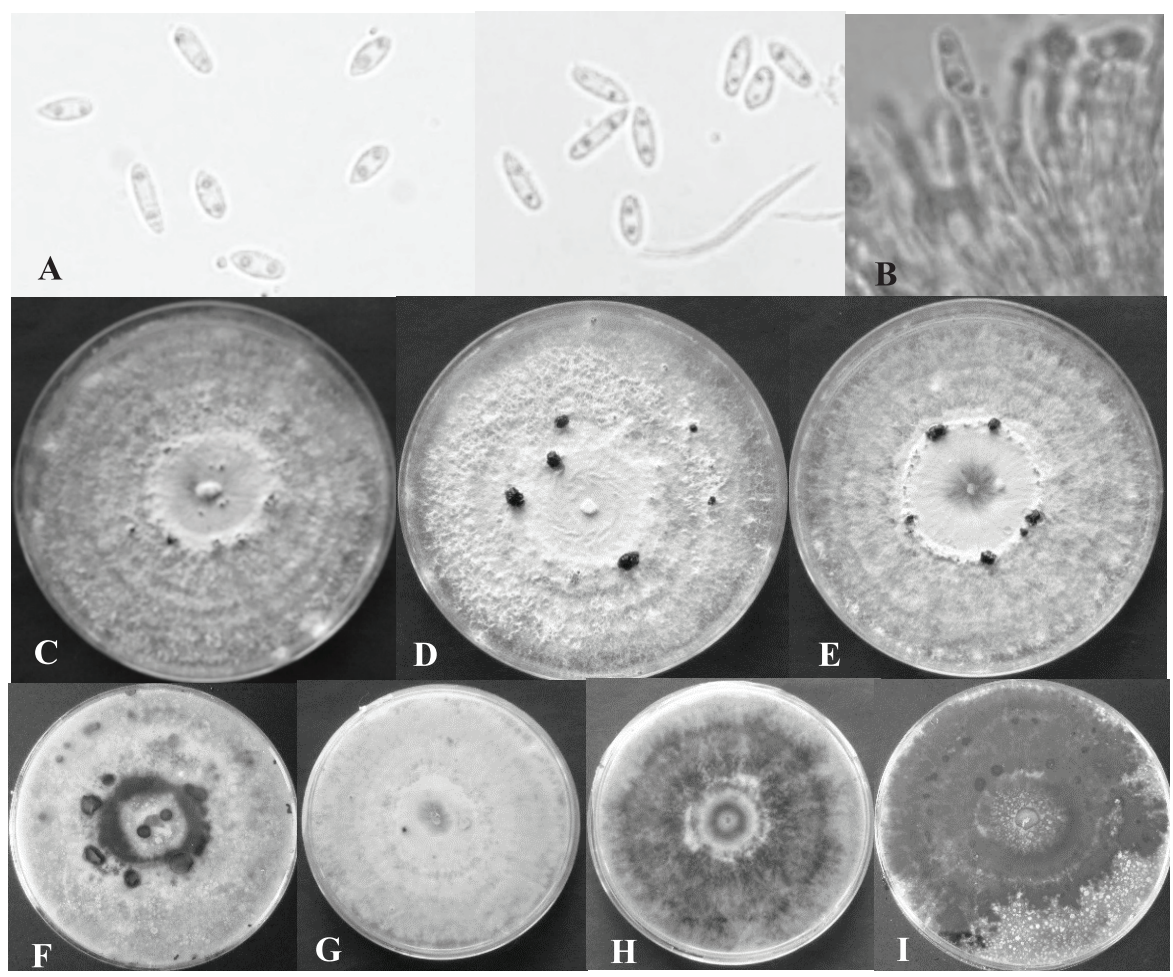

Figure 3. Morphological features of $P$. vaccinii isolates on PDA. A - $\alpha$ - and $\beta$-conidia in culture $(400 \mathrm{x})$. $\mathrm{B}$ - conidiophores and $\alpha$-conidia $(400 \mathrm{x})$. C - grayish brown mycelia and pycnidia in circle. Grayish white mycelia, without zonate and scattered pycnidia (D) and grouped pycnidia in circle (E). Revers pigmentation: dark brown centre, at the edge grayish white (F), creamy white (G), dark brown (H), dark gray (I).

Morphological characteristics of $\boldsymbol{P}$. vaccinii isolates on PDA

Table 5

\begin{tabular}{|c|c|c|c|c|c|c|}
\hline Zonate & Colony pigmentation & Percent & Pycnidia & Percent & $\begin{array}{l}\text { Number of } \\
\text { pycnidia }\end{array}$ & Percent \\
\hline \multirow{6}{*}{$\begin{array}{c}\text { Mycelium } \\
\text { formed } \\
\text { circles }\end{array}$} & $\begin{array}{l}\text { dark centre and at the } \\
\text { edge grayish white }\end{array}$ & 43.6 & \multirow{2}{*}{ in circles } & \multirow{2}{*}{41.0} & $0-10$ & 38.5 \\
\hline & creamy white & 30.8 & & & $11-20$ & 28.2 \\
\hline & dark brown & 15.4 & \multirow{2}{*}{ scattered } & \multirow{2}{*}{59.0} & \multirow{2}{*}{$>21$} & \multirow{2}{*}{33.3} \\
\hline & dark grey & 10.3 & & & & \\
\hline & Total & 100.0 & \multirow[b]{2}{*}{ Total } & 100.0 & \multirow[b]{2}{*}{ Total } & 100.0 \\
\hline & & & & & & $N=39$ \\
\hline \multirow{5}{*}{ No circle } & creamy white & 60.0 & \multirow{2}{*}{ scattered } & \multirow{2}{*}{100} & $0-10$ & 40.0 \\
\hline & dark brown & 40.0 & & & $11-20$ & 40.0 \\
\hline & & 1000 & \multirow{3}{*}{ Total } & \multicolumn{2}{|c|}{$100 \stackrel{>21}{1}$} & 20.0 \\
\hline & Total & & & \multirow{2}{*}{$N=5$} & \multirow{2}{*}{ Total } & 100.0 \\
\hline & & $N=5$ & & & & $N=5$ \\
\hline
\end{tabular}


The length and width of $P$. vaccinii $\alpha$-conidia from different cranberry growing regions in Latvia $(\mu \mathrm{m})$

Table 6

\begin{tabular}{|c|c|c|c|c|c|c|}
\hline & & Rucava & Babite & Alsunga & Ape & Pargauja \\
\hline \multirow{5}{*}{ length } & average & 7.35 & 7.55 & 7.48 & 6.88 & 7.27 \\
\hline & $\min$ & 5.16 & 5.19 & 5.72 & 5.02 & 5.14 \\
\hline & $\max$ & 10.99 & 10.94 & 10.03 & 8.81 & 8.84 \\
\hline & standard deviation (SD) & 0.86 & 0.89 & 0.85 & 0.67 & 0.69 \\
\hline & standard error (SX) & 0.028 & 0.029 & 0.049 & 0.047 & 0.069 \\
\hline \multirow{5}{*}{ width } & average & 2.77 & 2.88 & 3.02 & 2.58 & 2.62 \\
\hline & $\min$ & 1.49 & 1.75 & 1.70 & 1.89 & 1.79 \\
\hline & $\max$ & 4.08 & 4.00 & $4, .40$ & 3.55 & 3.43 \\
\hline & standard deviation (SD) & 0.39 & 0.34 & 0.44 & 0.34 & 0.27 \\
\hline & standard error $(\mathrm{SX})$ & 0.013 & 0.011 & 0.025 & 0.034 & 0.019 \\
\hline
\end{tabular}

Spore mass of conidia was creamy white, but the time when it appeared from pycnidia differed between isolates. $P$. vaccinii usually produced alpha $(\alpha)$ and beta $(\beta)$ conidia, but in this study mainly alpha conidia were observed.

The length and width of conidia were measured only from 26 isolates, because some colonies produced pycnidia, but did not produce spore mass, and some isolates did not produce any pycnidia at all.

In all isolates $\alpha$-conidia were hyaline, fusiform, ellipsoid, straight, aseptate, biguttulate. A few conidia of some isolates were relatively longer, with sharp apex, but most were with slightly rounded ends. The average size of $\alpha$-conidia $(\mathrm{n}=2600)$ was recorded: $7.4 \mu \mathrm{m}(5.0-10.9 \mu \mathrm{m})$ in length and $2.7 \mu \mathrm{m}(1.4$ $4.4 \mu \mathrm{m})$ in width. The isolates from Ape produced significantly shorter $(6.88 \mu \mathrm{m} ; \mathrm{SD}=0.67$; $\mathrm{SX}=0.047$; $\mathrm{p}<0.001) \alpha$-conidia than conidia from other regions (Table 6), and the length was also significantly different $(\mathrm{p}=0.001)$.
Other typical type of conidia ( $\beta$-conidia) was produced by only two isolates, one from Rucava and second from Ape (Figure 3, Table 7). The $\beta$-conidia were hyaline, filiform, straight or curved and aseptate. The length of $\beta$-conidia from Ape was significantly $(\mathrm{p}<0.001)$ higher $23.7 \mu \mathrm{m}( \pm 1.55 \mu \mathrm{m})$ than of those from Rucava $15.3 \mu \mathrm{m}( \pm 2.62 \mu \mathrm{m})$ and the width were significantly different $(\mathrm{p}=0.043) 1.6 \mu \mathrm{m}( \pm 0.19 \mu \mathrm{m})$ and $1.5 \mu \mathrm{m}( \pm 0.11 \mu \mathrm{m})$, respectively. Isolates were incubated at $+21{ }^{\circ} \mathrm{C}$ in dark more than three months for conidia formed, but no more colonies produced $\beta$-conidia, probably the reason was air temperature, because optimal temperature for $P$. vaccinii is above $25{ }^{\circ} \mathrm{C}$. Therefore, probably $P$. vaccinii cannot produce $\beta$-conidia in field conditions in Latvia. No information about relationships between $\alpha$ - and $\beta$-conidia of $P$. vaccinii on pathogenicity or aggressiveness was found in literature. 


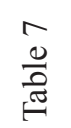

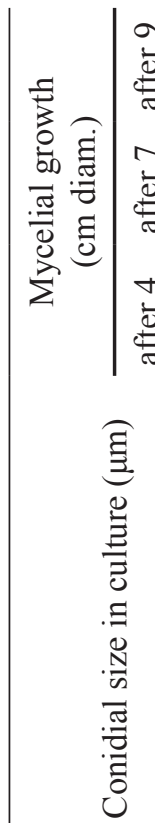

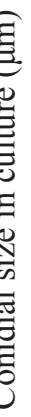

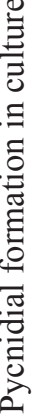

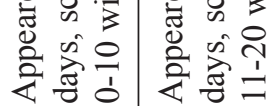

4
0
0
0
0
0
0
0
0
0
0
0
0
0
0
0



$\checkmark \stackrel{0}{0}$

苛

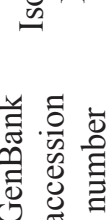

$\stackrel{\star}{\infty}$

i

$\mathrm{in}$

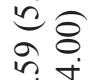

$\pi \frac{1}{1.1}$

$\because \frac{\pi}{\vec{y}}$

:

iे के

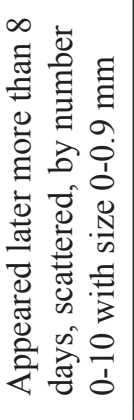

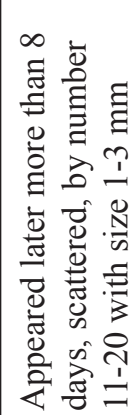

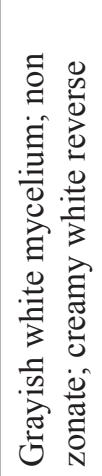

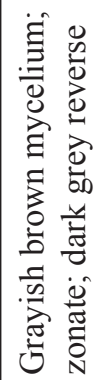

$\stackrel{\frac{\pi}{0}}{\frac{\pi}{\pi}}$

跑

2

空

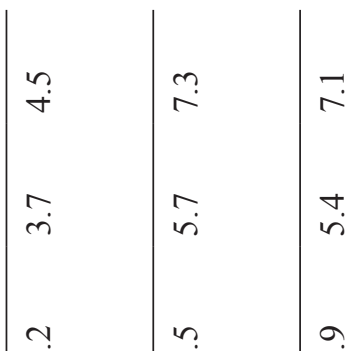

.

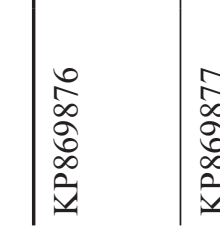

a

खें

离志目

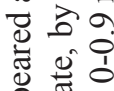

运芯

产

咅

芯

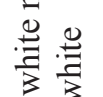

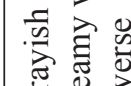

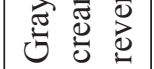

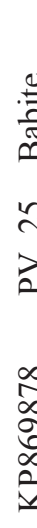

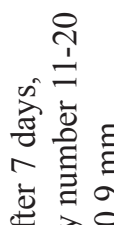

矛至

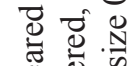

㐏总

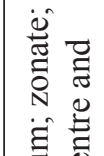

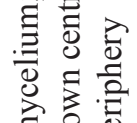

实

学妾产

ज承

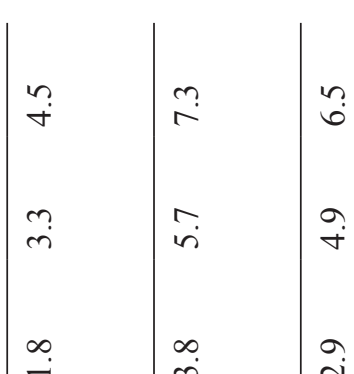




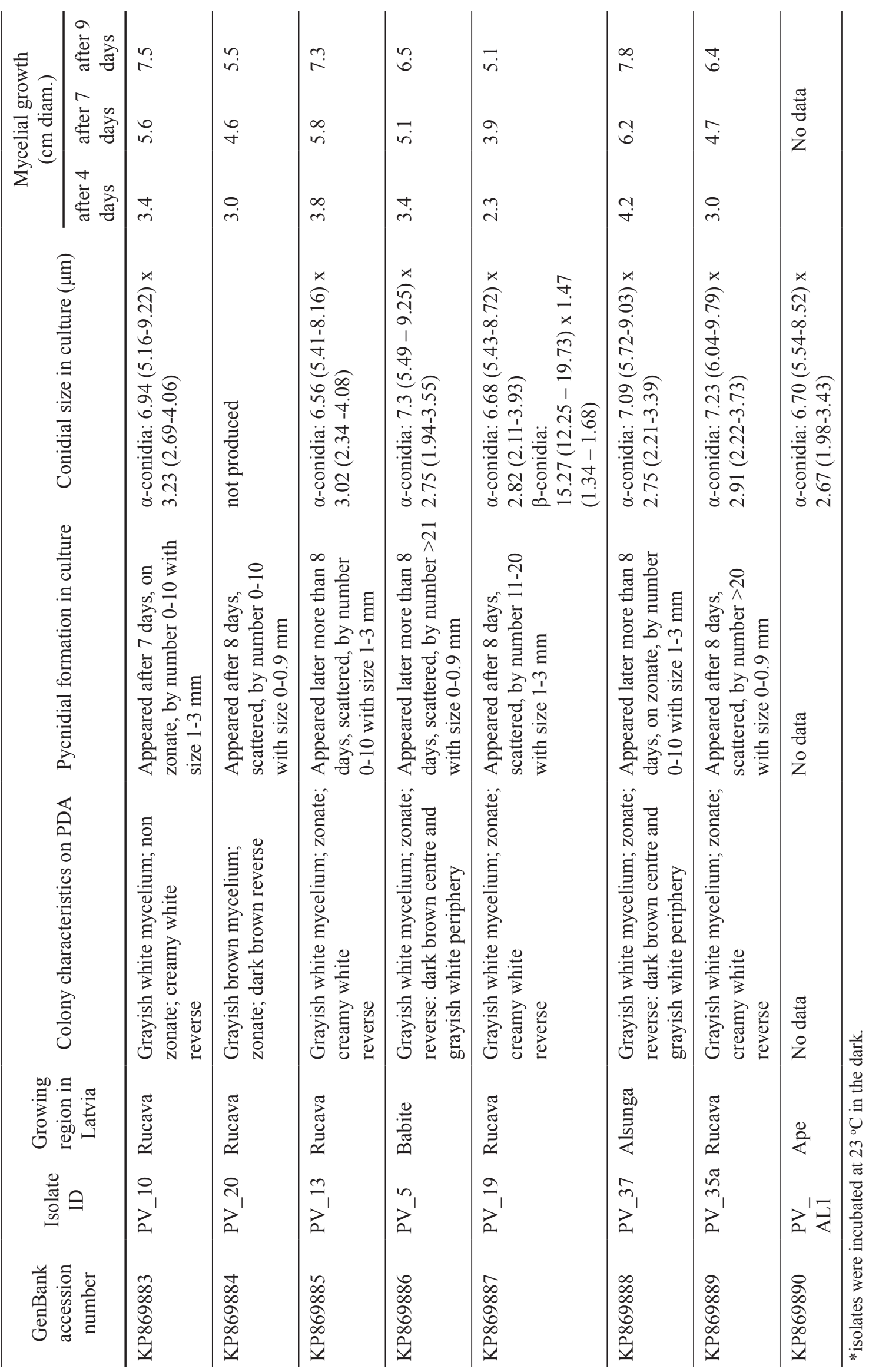




\section{Discussion}

$P$. vaccinii is associated with several diseases of plants from genus Vaccinium, but relationship between a host plant and pathogen can also be different like endophyte and nectrotroph life styles (Kačergius et al., 2004, Udayanga et al., 2011). Identification of $P$. vaccinii is often difficult and timeconsuming using only classical disease identification methods, and with introducing molecular methods and data bases, progress in speed and accuracy of identification of $P$. vaccinii and other Phomopsis species has been achieved (Farr et al., 2002, Kačergius et al., 2004, Udayanga et al., 2011, Udayanga et al., 2014a, 2014b). Nowadays even conformation of taxonomical identity by molecular approach is needed. It is not always possible to analyze a large number of samples, and accurate selection of isolates by morphological features is still essential.

$P$ vaccinii colonies grew well on PDA, but previously reported growth rate differs between researchers: after 3 days they showed $3.5 \mathrm{~cm}$ (Diaporthe vaccinii, 2009), after 7 days colonies reached $6.2 \mathrm{~cm}$ (Kačergius et.al., 2004) on average, but after 8 days $2.7-4.8 \mathrm{~mm}$ in diameter, if grown at $25^{\circ} \mathrm{C}$ (Farr et.al., 2002), and these studies confirm data about the growth rate obtained in this study colonies of $P$. vaccinii isolates could develop with different growth rate.

The main part of $P$. vaccinii isolates from this study in culture produced grayish white mycelia, like usually described in literature (Caruso and Ramsdel, 1995, Farr et.al.2002, Kačergius et al., 2004), but isolates of $P$. vaccinii with grayish (from cranberry) and yellow to brownish orange (from blueberry) mycelium were also reported (Farr et al., 2002). The other Phomopsis species can also produce similar colors and structures of mycelium (Gomes et al., 2013; Udayanga et al., 2014a, 2014b).

Although $P$. vaccinii has been described in literature as usually producing circle or zonate of mycelia and always forming pycnidia there (Caruso and Ramsdell, 1995, Kačergius et al, 2004), in this study the most part of $P$. vaccinii isolates formed pycnidia scattered, with a few pycnidia on circle. Some researchers (Farr et al., 2002) observed this feature, but others noticed that colonies on MEA usually produced scattered pycnidia (Kačergius et al., 2004). Three isolates from different geographic locations did not produce pycnidia (Farr et al., 2002).

$P$. vaccinii after 7-10 days formed 1-3 mm large pycnidia, partly embedded in substrate, maturing after 20-28 days (Caruso and Ramsdell, 1995; Kačergius et al., 2004, Diaporthe vaccinii, 2009).

Conidial size of $P$. vaccinii slightly differs as described by researchers in literature. Alpha conidia of $P$. vaccinii were 6-11 $\mu \mathrm{m}$ long and $2.5 \mu \mathrm{m}$ wide as measured in 1931 (Shear et al., 1931) and also in 1995 (Caruso and Ramsdell, 1995) in the USA, but in recent years $5.9-11.3 \mu \mathrm{m}$ long $(\mathrm{SD}=0.26, \mathrm{n}=500)$ and 2.1-3.9 $\mu \mathrm{m}$ wide $(\mathrm{SD}=0.8)$ were recorded in the USA (Farr et al., 2002) and $7-8 \times 2.5 \mu \mathrm{m}$ in Lithuania (Kačergius et.al., 2004); hyaline, fusiform, straight, guttulate, aseptate, forming creamy white to yellowish spore mass (Farr et al., 2002, Kačergius et al., 2004). Beta conidia was recorded 12-18 x $0.75 \mu \mathrm{m}$ (Caruso and Ramsdell, 1995) and 18-25 x $1.5 \mu \mathrm{m}$ (Kačergius et al., 2004) hyaline, filiform, straight or curved, egguttulate, aseptate, but not always performed (Caruso and Ramsdell, 1995, Farr et al., 2002, Kačergius et al., 2004). Many of other Phomopsis species produce similar features of conidia like $P$. vaccinii (Gomes et al., 2013, Udayanga et al., 2004a, 2014b), it means characteristics of conidia do not permit precise identification of the species.

During this study many features of $P$. vaccinii isolates from viscid rot of cranberry in culture on PDA were described, but almost all isolates were slightly different (Table 7), and we were not able to provide one average uniform description, so this is the reason why it can be easily confused with other Phomopsis species if classical phytopathological methods only are used. 1000 species of Phomopsis have been described and many of them have morphological plasticy (Santos and Phillips, 2009, Udayanga et al., 2004a, 2014b).

The result of this study showed no geographic similarities between the isolates of $P$. vaccinii, as it was concluded by other authors, too (Farr et al., 2002).

\section{Conclusions}

Colonies of $P$. vaccinii from cranberry plantations in Latvia showed different morphological features in culture, which made the identification of $P$. vaccinii difficult and complicated.

$P$. vaccinii mostly produced grayish white mycelium with creamy white pigmentation in reverse and zonate in the centre, formed large size (1-3 mm) pycnidia after 7-8 days, but not always on zonate.

No relationship between $P$. vaccinii morphological features and cranberry growing regions was found.

Morphological diversity of $P$. vaccinii probably indicated to potential variability of pathogen.

\section{References}

1. Bergman, H.F., Wilcox, M.S. (1936). The distibution, cause, and relative importance of cranberry fruit rots in Massachusetts in 1932 and 1933, and their control by spraying. Phytopathology, 26, 656-664. 
2. Caruso, F.L., Ramsdell, D.C. (1995). Cranberry diseases. In F.L. Caruso \& D.C. Ramsdell (Eds.), Compendium of Blueberry and Cranberry Diseases (pp. 27-47). APS Press, St. Paul, MN.

3. Diaporthe vaccinii (2009) Bulletin OEPP/EPPO Bulletin, 39, 18-24.

4. European Food Safety Authority (2014). EFSA Panel on Plant Health, Scientific Opinion on the pest categorisation of Diaporthe vaccinii Shear. EFSA Journal, 12 (7), 3774, $28 \mathrm{p}$.

5. Farr, D.F., Castlebury, L.A., \& Rossman, A.Y. (2002). Morphological and molecular characterization of Phomopsis vaccinii and additional isolates of Phomopsis from blueberry and cranberry in the eastern United states. Mycologia, 94(3), 494-504.

6. Gomes, R.R., Glienke, C., Videira, S.I.R., Lombard, L., Groenewald, J.Z., \& Crous, P.W (2013). Diaporthe: a genus of endophytic, saprobic and plant pathogenic fungi. Persoonia, $31,1-41$.

7. Kačergius, A., Gabler, J., Jovaišiene, Z. (2004). Detection of Phomopsis canker and dieback of highbush blueberries and cranberries in Lithuania. Agronomy Research, 7, 71-78.

8. Kačergius, A., Jovaišienė Z. (2010). Molecular characterization of quarantine fungus Diaporthe/ Phomopsis vaccinii and related isolates of Phomopsis from Vaccinium plants in Lithuania. Botanica Lithuanica, 16(4), 177-182.

9. Lombard, L., Van Leeuwen, G.C.M., Guarnaccia, V., Polizzi, G., Van Rijswick, P.C.J., Rosendahl, K.C.H.M., Gabler, J., Crous, P.W. (2014). Diaporthe species associated with Vaccinium, with specific reference to Europe. Phytopathologia Mediterranea, 53(2), 287-299.

10. Santos, J.M., Phillips, A.J.L. (2009). Resolving the complex of Diaporthe (Phomopsis) species occurring on Foeniculum vulgare in Portugal. Fungal Diversity, 34, 111-125.

11. Shear, C.L., Stevens, N.E., Bain, H.F. (1931). Fungous diseases of the cultivated cranberry. Technical Bulletin, 258, 2-4.
12. Tamura, K., Peterson, D., Peterson, N., Stecher, G., Nei, M., Kumar, S. (2011). MEGA5: Molecular Evolutionary Genetics Analysis Using Maximum Likelihood, Evolutionary Distance, and Maximum Parsimony Methods. Molecular Biology and Evolution, 28, 27312739.

13. Udayanga, D., Liu, X., McKenzie, E.H.C., Chukeatirite, E., Bahkali, A.H.A., Hyde, K.D. (2011). The genus Phomopsis: biology, applications, species concept and names of common phytopathogens. Fungal Diversity, 50, 189-225.

14. Udayanga, D., Castlebury, L.A., Rossman, A.Y., Hyde, K.D. (2014a). Species limits in Diaporthe: molecular re-assessment of $D$. citri, $D$. cytosporella, D. foeniculina and D. rudis. Persoonia, 32, 83-101.

15. Udayanga, D., Castlebury, L.A., Rossman, A.Y., Chukeatirote, E., Hyde, K.D. (2014b). Insights into the genus Diaporthe: phylogenetic species delimitation in the $D$. eres species complex. Fungal Diversity, 67, 203-229.

16. Ulloa, M., Hanlin, R.T. (2000). Illustrated Dictionary of Mycology. The American Phytopathological Society, St. Paul, Minnesota, USA, 448 pp.

17. Vilka, L., Bankina, B. (2013). Incidence of cranberry (Vaccinium macrocarpon Ait.) storage rot in Latvia. Proceedings of the Latvian Academy of Sciences. Section B, 67(2), 179183.

18. Vilka, L., Rancane, R., Eihe, M. (2009). Fungal diseases of Vaccinium macrocarpon in Latvia. Agronomy Research, 12, 125-133.

19. Weingartner, D.P., Klos, E.J. (1975). Etiology and symptomatology of canker and dieback diseases on highbush blueberries caused by Godronia (Fusicoccum) cassandrae and Diaporthe (Phomopsis) vaccinii. Phytopathology, 65, 105-110. 